\title{
КОМУНІКАТИВНИЙ МЕТОД У ПРОФЕСІЙНО-ОРІЕНТОВАНОМУ ПІДХОДІ ДО НАВЧАННЯ УКРАЇНСЬКОЇ МОВИ ІНОЗЕМНИХ СТУДЕНТІВ МЕДИЧНИХ СПЕЦІАЛЬНОСТЕЙ
}

\author{
ТЕТЯНА ЛЯХ \\ Ужгородський національний університет, Ужгород - Україна \\ tatianalyakh592@gmail.com; ORCID: 0000-0002-7913-3468

\begin{abstract}
METODA KOMUNIKACYJNA W ZORIENTOWANYM ZAWODOWO PODEJŚCIU DO NAUCZANIA JĘZYKA UKRAIŃSKIEGO ZAGRANICZNYCH STUDENTÓW KIERUNKÓW MEDYCZNYCH
\end{abstract}

TETIANA LACH

Użhorodzki Uniwersytet Narodowy, Użhorod - Ukraina

\begin{abstract}
STRESZCZENIE. Funkcjonowanie metody komunikacyjnej w zawodowym podejściu do nauczania języka ukraińskiego studentów zagranicznych kierunków medycznych jest mało zbadane, co uwarunkowuje aktualność tego tematu. Stwierdzono, że badacze różnią się w swojej opinii na temat roli komponentu komunikacyjnego i gramatycznego w nauczaniu języka ukraińskiego jako języka obcego. Ponadto współczesne podręczniki nie mają wystarczającej liczby ćwiczeń, aby rozwinąć komunikację zawodową. Celem pracy jest poznanie zastosowania metody komunikatywnej w profesjonalnym podejściu do nauczania języka ukraińskiego (jako języka obcego), opracowanie odpowiednich ćwiczeń i zadań. Stwierdzono, że w procesie uczenia się komunikacji w języku obcym istotne jest przedstawienie i opanowanie materiału gramatycznego przez studentów. Przedstawiono przykłady zadań i ćwiczeń mających na celu rozwój kompetencji komunikacyjnych i gramatycznych studentów-medyków zagranicznych w zakresie komunikacji zawodowej.
\end{abstract}

Słowa kluczowe: metoda komunikacyjna, kompetencje komunikacyjno-gramatyczne, język ukraiński, komunikacja zawodowa, zadanie, ćwiczenie, studenci zagraniczni 


\title{
COMMUNICATIVE METHOD \\ IN PROFESSIONALLY-ORIENTED TEACHING \\ OF UKRAINIAN LANGUAGE \\ FOR THE FOREIGN STUDENTS OF MEDICINE
}

\author{
TETIANA LIAKH \\ Uzhhorod National University, Uzhhorod - Ukraine
}

\begin{abstract}
The way the communicative method functions in a professionally oriented approach to teaching Ukrainian foreign students of medical specialties has been little studied, and that determines the relevance of this topic. It has been found that there is a controversy in scientific thought concerning the role of both communicative and grammar components of teaching Ukrainian as a foreign language. Moreover, modern textbooks do not provide sufficient exercises to develop professional communication. The purpose of this study is to investigate the application of the communicative method in a professionally oriented approach to teaching Ukrainian (as a foreign language), and to develop appropriate exercises and tasks. The conclusion is that in the process of learning to communicate in a foreign language, it is important for students to present and master grammatical material. Samples of tasks and exercises aimed at developing the communicative and grammar competence of foreign medical students in professional communication are presented.
\end{abstract}

Keywords: communicative method, communicative-grammatical competence, Ukrainian, professional communication, task, exercise, foreign students

$\mathrm{H}$ авчальна дисципліна „Українська мова” для студентів-іноземців у вищих навчальних закладах нефілологічного профілю є важливою складовою державної освітньої програми України щодо підготовки спеціалістів для зарубіжних країн. Головна мета викладача української мови - навчити іноземних студентів мовленнєвій діяльності з метою забезпечення комунікативних потреб у соціально-культурній сфері в період адаптації в новому інакомовному середовищі та формування мовної компетенції в навчально-професійній сфері. Ці завдання досягаються через комплексний підхід, який об'єднує комунікативні, освітні і виховні цілі. Дослідниці Н. Ушакова та О. Тростинська справедливо відзначають, що „процес мовної освіти іноземців реалізується в єдності трьох напрямів: комунікативного (мета - комунікативна компетенція), загальнонаукового (мета - загальнонаукова/ професійна компетенція), адаптаційного (мета акультурація до реалій і завдань життєдіяльності в іншомовному середовищі)" [Ушакова, Тростинська 2014: 13-14]. За вказаними напрямами розробляються сучасні методи викладання української мови іноземним студентам.

Сучасні дослідники відводять першорядну роль у навчанні мови саме комунікативному методу і виділяють у ньому ряд загальнодидактичних і методичних принципів. За Б. Соколом, комунікативний метод включає: 
а) принцип мовленнєво-мисленнєвої активності - передбачає, що будьякий мовленнєвий матеріал (фраза, текст) активно використовується носіями мови у процесі спілкування;

б) принцип індивідуалізації - головний засіб створення мотивації при оволодінні мовою;

в) принцип функціональності - відповідно до цього принципу визначаються функції говоріння, читання, аудіювання і письма як засобу спілкування;

г) принцип ситуативності - передбачає визнання ситуації як базової одиниці організації процесу навчання іншомовного спілкування;

д) принцип новизни - забезпечує підтримку інтересу до оволодіння іноземною мовою, формування мовленнєвих навичок, розвиток продуктивності й динамічності мовленнєвих умінь [Сокіл 2007: 17-18].

Як бачимо, основне завдання комунікативного методу - розвиток мовлення іноземних студентів з використанням матеріалу, який безпосередньо забезпечують носії мови. Важливим у професійному підході до вивчення мови є принцип „ситуативної” організації процесу навчання. При професійно-орієнтованому підході мовні ситуації відповідають певним фаховим умовам. У таких ситуаціях студент, на думку О. Канюк, „міг би вільно застосовувати набуті знання з іноземної мови, використовуючи граматичні та лексичні навички для виконання певних професійних завдань" [Канюк 2019: 236]. О. Вдовіна вважає, що „навчальна діяльність іноземних студентів повинна організовуватися так, щоб вони виконували дії, які є мотивованими для вирішення комунікативних завдань” [Вдовіна 2019: 49]. Стратегії мовленнєвої поведінки „,з використанням мови у конкретних мовленнєвих актах” у процесі навчання відзначає Л. Субота [Субота 15: 318].

Важливим моментом у професійно-орієнтованому підході до навчання мови є спосіб подачі граматичного матеріалу. Науковці також указують на недоліки комунікативного методу. Наприклад, за спостереженням С. Король, „результати аналізу деяких комунікативних підручників показали, що граматика подається дещо «розірвано» і таким чином втрачається певна системність мови" [Король 2012: 134].

Комунікативний метод передбачає навчання граматики таким чином, щоб насамперед покращувався процес спілкування. За словами А. Гаврилюк, „при навчанні за комунікативним методом граматика необхідна лише для правильної побудови речень, проте від студентів вимагається не механічне заучування граматичних правил, а інтуїтивне відчуття правильно побудованих фрагментів мовлення" [Гаврилюк 2012].

Нам імпонують думки тих дослідників, котрі вважають, що комунікативну спрямованість навчання треба організувати шляхом гармонійного засвоєння фонетичного, граматичного, лексичного матеріалу. Так, на думку Н. Ушакової, „роль граматики іноземної мови у формуванні вторинної мовної 
особистості можна окреслити як світоглядну, системоутворюючу" [Ушакова 2014: 66]. Подібні думки знаходимо у Л. Селівестрової, котра зазначає: „вивчення готових фраз у ситуативному підході не може, звісно, забезпечити оволодіння українською мовою як іноземною, оскільки оволодіння мовою можливе тільки тоді, коли засвоєння мовленнєвого матеріалу веде до формування в іноземця системи мови, коли він може будувати фрази відповідно до правил граматичного оформлення і слововживання в акті спілкування" [Селівестрова 2007: 10].

Особливо необхідною є взаємодія граматичного і комунікативного компонентів навчання української мови за професійним спрямуванням. Л. Боднарюк, вивчаючи специфіку навчання української мови студентів-іноземців медичних ВН3, наголошує, що у процесі навчання англомовних студентів викладач має сформувати в них такі компетентності:

артикуляційні (правильна вимова звуків, інтонація, ритміка); мовні (знання базових лексичних одиниць, оволодіння певними правилами їхньої трансформації в граматично правильне осмислене висловлювання); комунікативні (знання вербальних і невербальних засобів та способів висловлення думок, почуттів у різних сферах спілкування відповідно до ситуацій і тем спілкування, уміння використовувати мовні засоби на практиці, вести діалог) [Боднарюк 2017: 219-220].

Отже, комунікативний метод у навчанні української мови як іноземної викликає зацікавлення з боку науковців. Однак існує певна розбіжність їхніх думок щодо ролі комунікативної та граматичної складової у процесі навчання української мови як іноземної. Актуальність цього дослідження зумовлена тим, що, попри значну увагу вчених до комунікативного методу, його застосування у професійно-орієнтованому підході до навчання української мови іноземних студентів медичних спеціальностей досліджене недостатньо.

Професійно-орієнтований підхід до вивчення української мови для іноземних студентів-медиків $\epsilon$ надзвичайно важливим у зв'язку з тим, що клінічні заняття із фахових дисциплін, медичну практику, а подекуди й інтернатуру вони проходять на базі українських лікарень, тому для спілкування з українськими колегами та пацієнтами необхідні навики комунікації в певних професійних ситуаціях. Отож, одним із компонентів змісту навчання української мови є здатність іноземних студентів розуміти висловлювання, а також використовувати інформацію під час спілкування у професійній сфері. У зв'язку з цим у процесі навчання української мови іноземних студентів медичного профілю відчувається брак відповідних методичних прийомів, завдань і вправ. Тому виникає необхідність вивчення застосування комунікативного методу та розробки комплексу комунікативно-орієнтованих завдань, відбору граматичного матеріалу в межах професійних ситуацій у навчанні 
української мови іноземних студентів-медиків. Мета дослідження - вивчити застосування комунікативного методу у зв'язку із професійно-орієнтованим підходом до навчання української мови, розробити відповідні вправи і завдання, які сформують в іноземних студентів-медиків комунікативно-граматичну компетенцію в їхньому професійному спілкуванні.

Для ефективного навчання української мови у професійному спрямуванні насамперед необхідним $€$ забезпечення студентів відповідними навчально-методичними матеріалами. Л. Паламар відзначає важливість комунікативно-діяльнісного підходу до навчання української мови як іноземної та наголошує, що у підручниках такого типу

всі дібрані мовні явища розглядаються в контексті мовленнєвої діяльності [...], основне завдання викладача - підготувати студента, який володіє вміннями комунікативно доцільно вживати мовні засоби у різних сферах і видах мовленнєвої діяльності не лише під час навчання в аудиторії, а й в позааудиторний час [Паламар 2008: 43].

Ці рекомендації ми врахували при розробці навчально-методичного посібника для іноземних студентів медичних спеціальностей вищих закладів освіти, котрі вивчають українську мову на завершальному етапі [Лях 2018]. Метою посібника $є$ сформувати в іноземних громадян високий рівень комунікативної компетентності у професійній сфері, розвинути вміння й навички фахової мовленнєвої діяльності, брати участь у професійно зорієнтованій діалоговій комунікації, сприяти творчій самореалізації під час спілкування. Посібник містить 10 найбільш актуальних комунікативних тем професійного мовлення лікаря, наприклад, „У сімейного лікаря”, „В отоларинголога”, „У пульмонолога”, „У кардіолога”, „В аптеці” тощо. До кожної теми поданий граматичний матеріал, лексика за фахом, тексти для читання і перекладу, завдання для закріплення вивченого матеріалу, вправи комунікативно-ситуаційного характеру, моделі мовленнєвих ситуацій на різних етапах комунікативної взаємодії лікаря з пацієнтом. Практичний курс призначено як для аудиторної роботи, так і для самостійного опрацювання та самоконтролю.

Формування комунікативної компетентності в іноземних студентів-медиків буде більш ефективним за умови впровадження таких завдань і вправ, що сприятимуть засвоєнню як граматичного матеріалу, так і вдосконаленню навиків спілкування у професійній сфері. У зв'язку з цим навчання граматики повинно відбуватися в рамках комунікативного підходу з акцентом на функції мовних структур у ситуаціях, характерних для сфери професійної діяльності студентів. За спостереженням I. Кожушко, „під час реалізації комунікативного підходу інформація про граматичні форми вводиться в контексті роботи над ними, щоб студенти могли бачити, як вони використовуються для передачі значення" [Кожушко 2015: 46]. $з$ цією метою нами було проведено відбір 
граматичного матеріалу з точки зору його необхідності у процесі формування комунікативної компетенції у іноземних студентів-медиків.

Прикладом формування комунікативної компетенції може бути вивчення орудного відмінка (у поєднанні з іншими відмінками) із застосуванням відповідних граматичних конструкцій на позначення способу дії:

\begin{tabular}{|l|l|}
\hline що (Noт. сале) & шляхом/by means of (Abl. case) чого (Gen. case) \\
відбувається/ & методом/by method (Abl. case) чого (Gen. case) \\
take place & за допомогою/ by dint of (Abl. case) чого (Gen. case) \\
& під дією, впливом/under the action/influence (Abl. case) чого (Gen.case) \\
\hline
\end{tabular}

Після засвоєння студентами вказаного матеріалу наступним кроком може бути виконання таких вправ:

I. Прочитайте запитання і дайте на них відповіді, зверніть увагу на вживання орудного відмінка в реченнях.

Чим збільшують зображення? (Орієнтовна відповідь: - Зображення збільшують оптичною частиною мікроскопа).

За допомогою чого досліджують непрозорі та напівпрозорі об'єкти? (Орієнтовна відповідь: - Непрозорі та напівпрозорі об 'єкти досліджують за допомогою опак-ілюмінатора.

Яким чином здійснюють вимірювання під мікроскопом? (Орієнтовна відповідь: - Вимірювання під мікроскопом здійснюють за допомогою окуляр-мікроскопа.

II. Утворіть речення, де йдеться про використання інструментів, наведених уключі, наприклад: 1. Хворий міряе температуру термометром. 2. 3 а допомогою термометра хворий міряє температуру.

Ключ: Пінцет, піпетка, термометр, амперметр, вольтметр, мікрофотокамера, мікропроектор, люмінесиентний мікроскоп.

Вивчення граматики можна вдало поєднати із засвоєнням студентами термінологічної лексики, що являє собою важливий етап становлення фахової комунікативної компетенції. М. Тишковець слушно зазначає, що „перший крок до освоєння мови за допомогою комунікативного методу - запам'ятовування слів, виразів, а вже потім накладання наявних знань на їх граматичну основу" [Тишковець 2013: 42]. Тому у професійно-орієнтованому підході до навчання української мови студентів-іноземців значну увагу слід приділяти вивченню лексики за фахом, найнеобхідніших слів і виразів.

Приклад комплексу завдань, спрямованих на збагачення лексичного матеріалу, необхідного для комунікації, створення власних словників у процесі вивчення прикметників:

I. Утворіть словосполучення, поєднуючи слова з лівої і правої колонок. Наприклад: Біль має нападоподібний характер. 


\begin{tabular}{|l|l|}
\hline біль (pain) & $\begin{array}{l}\text { нападоподібний (attak), тупий (obtuse, dull), } \\
\text { гострий (acute), piжучий (cut), колючий (prickly) } \\
\text { тягучий (drudge; dull), ниючий (slobber) } \\
\text { стискаючий (pressing), пульсуючий (pulsing). }\end{array}$ \\
\hline
\end{tabular}

II. Оберіть відповідні прикметники (подані у ключі) до наведених іменників

Біль, напад, синдром, голодування, судини.

Ключ. Сильний, слабкий, дрібний, великий, тупий, гострий, клінічний, кисневий, коронарний, тривалий, закономірний.

III. Утворіть речення, використовуючи подані прикметники. За потреби скористайтеся тлумачним словником

Клітинний, клітчастий, міжклітинний, багатоклітинний, внутрішньоклітинний; кислий, кислотний, кислуватий, кислотостійкий; кістковий, кісточковий, кістлявий; кровоносний, кровотворний, кров'янистий; спеціальний, спеціалізований, специфічний.

Вивчення нової фахової лексики можна доповнити граматичним завданням. Прикладом може бути вправа на переклад, за допомогою якої студенти відшліфовують навики утворення граматичних форм:

Перекладіть речення, звертаючи увагу на вживання відмінків.

1. Ваше серие і легені потрібно перевірити. 2. Зробіть електрокардіограму. 3. Зробіть аналізи крові та сечі [Лях 2018: 39].

Сьогодні актуальним у формуванні комунікативної компетентності іноземних студентів є застосування інтерактивних технологій у процесі навчання української мови. У Загальноєвропейських Рекомендаціях з мовної освіти (Common European Framework of Reference for Languages: Learning, teaching, assessement) стратегію інтеракції розглядають у кілька етапів:

планування, що складається з конструювання, визначення прогалин в інформації і точках зору, прийняття рішення про передбачення, розгортання плану; виконання, що включає вступ до розмови, міжособистісну співпрацю, «ідейну» співпрацю, інтерпретацію несподіваного, запит про допомогу; оцінювання [Загальноєвропейські Рекомендації з мовної освіти 2003: 137-138].

До принципів інтерактивного навчання також відносять „принцип діалогічної взаємодії, принцип кооперації й співробітництва, принцип активно-рольової (ігрової) і тренінгової організації навчання” [Інтерактивні методи навчання 2005: 37]. Отже, інтерактивне навчання передбачає взаємодію викладача і студента, яка насамперед здійснюється в ході їхньої комунікації.

Дослідниця С. Сисоєва відзначає такі принципи інтерактивного навчання: „Принцип діалогічної взаємодії, принцип кооперації й співробітництва, принцип активно-рольової (ігрової) і тренінгової організації навчання” [Си- 
соєва 2007: 37]. Важливу роль у фаховій комунікації відіграють діалоги, моделювання ситуацій ділового спілкування. Тому тут ефективними стануть такі інтерактивні методи як „ігри-інсценівки (ігри-імітаціі)”. Зазвичай вони „грунтуються на розгляді фрагментів (чи повного набору) конкретної діяльності (того чи іншого виду), і відпрацьовують комунікативні навички" [IHтерактивні методи навчання 2005: 15]. Продуктивною є робота в парах, що дає студентові можливість не лише продемонструвати засвоєний матеріал, а й проявити власну індивідуальність. На думку Н. Азарової, „викладач може об'єднувати студентів у пари за їхнім бажанням або на власний розсуд, враховуючи рівень знань (сильний - слабкий), ступінь їхньої активності”; „пари можуть змінюватися впродовж заняття, що створює умови для залучення всіх студентів у роботу" [Азарова 2001: 8-9]. Для студентів-іноземців надзвичайно важливим $€$ ігровий метод, що відображає ситуації з професійного життя. Для вироблення навиків фахового мовлення майбутніх лікарів особливо продуктивною є робота в парах, відтворення діалогу „лікар - пацієнт”. Наприклад:

Дайте відповіді на питання лікаря, використовуючи наведені словосполучення.

Що вас турбує? На що ви скаржитесь? Коли ви захворіли? Коли настало погіршення? Які ознаки хвороби з'явилися спочатку? Які ознаки захворювання з'явилися пізніше? Де ви відчуваєте біль? Коли ви відчуваєте біль? Коли ви відчуваєте біль: У стані спокою чи фізичного навантаження? [Лях 2018: 50].

У фаховому спілкуванні важливу роль відіграє моделювання студентами комунікативних ситуацій професійного характеру. Одним із таких методів $\epsilon$ метод „продовження історії” (Chainstory), що „полягає у продовженні icторії попереднього студента" [Шумило 2016: 560]. Наприклад, студентам запропоновано такий початок розповіді: ,, Учора мені подзвонила моя подруга Олеся. Вона сказала, щуо ї чоловік захворів. У нього ...". (Можливі варіанти продовження: „... У нього висока температура, головний біль, камель, нежить. Олеся викликала лікаря. Лікар прийшов, оглянув хворого і сказав, щзо у нього грип. Він виписав рецепт і пояснив, як приймати ліки. Олеся побігла до аптеки. Там вона купила таблетки, краплі й мікстуру”). Також покращує логічне мислення та увагу гра „снігова куля”, яка „дещо відрізняється від попередньої гри у тому, що студентам потрібно не тільки доповнити розповідь, а й повторити історію із самого початку додавши своє речення" [Шумило 2016: 560].

Отже, використання комунікативного методу у професійно-орієнтованому підході до навчання української мови іноземних студентів вимагає поєднання різних типів завдань і вправ, які включають як напрацьовування граматичних компетентностей, так і роботу з фаховим текстом, запам'ятовування лексики з розмовних тем. Збільшенню розмовної практики сприяє використання інтерактивного навчання, що спонукає студентів висловлювати та аргумен- 
тувати власну думку засобами української мови у професійних ситуаціях. 3 цією метою доцільно застосовувати роботу в парах або у групах (рольові ігри „лікар - пацієнт”, дискусія тощо). Застосування комунікативного методу у професійно-орієнтованому підході до навчання української мови іноземних студентів-медиків є ефективним і потребує подальших досліджень та розробки комплексу вправ і завдань для практичного застосування.

\section{Список використаної літератури}

Азарова Н.В., Інтерактивні технології навчання майбутніх правників, [в:] „Психолого-педагогічні проблеми сільської школи: збірник наукових праць Уманського державного педагогічного університету ім. Павла Тичини", вип. 39, частина 2, с. 7-13.

Боднарюк Л., Специфіка навчання української мови студентів-іноземиів медичних ВНЗ У групах з англійською мовою викладання, [в:] „Педагогічні науки: теорія, історія, інноваційні технології”, 2017, № 5, с. 217-230.

Вдовіна О.О., Особливості формування комунікативної компетенції іноземних студентів, [in:] "Young Scientist", 2019, nr 5.1 (69.1), p. 47-50.

Гаврилюк А.П., Застосування комунікативного методу викладання іноземних мов У ВНЗ, [в:] Електронний ресурс: http://confesp.fl.kpi.ua/sites/default/files/onlayn_tezi_gavrilyuk. $\operatorname{pdf}(20.06 .2021)$.

Загальноєвропейські Рекомендаиії з мовної освіти: вивчення, викладання, оцінювання, Київ: Ленвіт, 2003.

Інтерактивні методи навчання: навч. посібник, за ред. П. Шевчука і П. Фенриха, Щецін: Вид-во WSAP, 2005.

Канюк О., Когнітивно-комунікативний підхід У методиџі викладання іноземної мови, [в:] „Сучасні дослідження з іноземної філології”, 2019, вип. 17, с. 231-239.

Кожушко І.А., Інноваџійні підходи та методи викладання експрес-курсу украӥнської мови як іноземної, [в:] „Викладання мов У вищих навчальних закладах освіти”, 2015, вип. 27, c. $42-50$.

Король С.В., Комунікативний підхід У навчанні іноземних мов, [в:] „Педагогічний дискурс", 2012, вип. 11, с. 133-136.

Лях Т.О., Украӥнська мова як іноземна: професійне мовлення. Практичний курс для іноземних студентів медичних спеціальностей В3О: Навчальний посібник, Ужгород: Говерла, 2018.

Паламар Л., Принципи укладання підручника з украӥнської мови для іноземних студентів, [в:] „Теорія і практика викладання української мови як іноземної”, 2008, вип. 3 , c. $40-47$.

Селівестрова Л., Лінгвістична та психологічна основа навчання украӥнської мови як іноземної, [в:] „Теорія і практика викладання української мови як іноземної”, 2007, вип. 2, c. $8-13$.

Сисоєва С.О., Інтерактивні технології навчання дорослих: навчально-методичний посібник, Київ: ВД „ЕКМО”, 2011. 
Сокіл Б., Методи вивчення української мови як іноземної та їх характеристика, [в:] „Теорія і практика викладання української мови як іноземної”, 2007, вип. 2, с. 14-18.

Субота Л., Комунікативна організачія наукового тексту У процесі професійної підготовки іноземних студентів немовного ВН3, [в:] „Наукові записки Національного університету «Острозька академія». Серія «Філологічна»”, 2015, вип. 53, с. 317-320.

Тишковець М., Використання комунікативного методу вивчення украӥнської мови як іноземної У медичному ВНЗ, [в:] „Теорія і практика викладання української мови як іноземної”, 2013, вип. 8, с. 40-48.

Ушакова Н.І., Когнітивні основи формування комунікативної компетентності іноземних студентів У підручнику з мови навчання, [в:] „Викладання мов У вищих навчальних закладах освіти на сучасному етапі. Міжпредметні зв’язки. Наукові дослідження. Досвід. Пошуки", 2014, вип. 25, с. 65-74.

Ушакова Н., Тростинська О., Вивчення української мови студентами-іноземиями: концептуальні засади, [в:] „Теорія і практика викладання української мови як іноземної”, 2014, вип. 9, с. 12-21.

Шумило I.І., Формування комунікативної компетентності студентів засобами інтерактивних технологій на заняттях іноземної мови, [в:] „Молодий вчений: Педагогічні науки”,2016, № 12.1 (40), с. 559-562.

\section{Spysok vykorystanoi literatury [References]}

Azarova N.V., Interaktyvni tekhnolohii navchannia maibutnikh pravnykiv [Interactive technologies for training future lawyers], [v:] „Psykholoho-pedahohichni problemy silskoi shkoly: zbirnyk naukovykh prats Umanskoho derzhavnoho pedahohichnoho universytetu im. Pavla Tychyny", 2011, vyp. 39, Chastyna 2, s. 7-13.

Bodnariuk L., Spetsyfika navchannia ukrainskoi movy studentiv-inozemtsiv medychnykh VNZ $u$ hrupakh z anhliiskoiu movoiu vykladannia [Specificity of the Ukrainian-language teaching of foreign students of medical universities in groups with English language teaching], [v:] „Pedahohichni nauky: teoriia, istoriia, innovatsiini tekhnolohii”, 20, nr 5, s. 217-230.

Vdovina O.O., Osoblyvosti formuvannia komunikatyvnoi kompetentsii inozemnykh studentiv [Features of formation of communicative competence of foreign students], [v:] "Young Scientist", 2019, nr 5.1 (69.1), s. 47-50.

Havryliuk A.P., Zastosuvannia komunikatyvnoho metodu vykladannia inozemnykh mov u VNZ [Application of the communicative method of teaching foreign languages in higher educational institutions], [v:] Elektronnyi resurs: http://confesp.fl.kpi.ua/sites/default/files/ onlayn_tezi_gavrilyuk.pdf (20.06.2021).

Zahalnoievropeiski Rekomendatsii z movnoi osvity: vyvchennia, vykladannia, otsiniuvannia [Common European Framework of Reference for Languages: Learning, teaching, assessement], Kyiv: Lenvit, 2003.

Interaktyvni metody navchannia: navch. Posibnyk [Interactive teaching methods: learner's guide], za red. P. Shevchuka i P. Fenrykha, Shchetsin: Vyd-vo WSAP, 2005. 
Kaniuk O., Kohnityvno-komunikatyvnyi pidkhid u metodytsi vykladannia inozemnoi movy [Communicative and cognitive approach in teaching foreign language], [v:] ,Suchasni doslidzhennia z inozemnoi filolohii”, 2019, vyp. 17, s. 231-239.

Kozhushko I.A., Innovatsiini pidkhody ta metody vykladannia ekspres-kursu ukrainskoi movy yak inozemnoi [Innovative approaches and methods of intensive teaching of Ukrainian language as a foreign language], [v:] ,Vykladannia mov u vyshchykh navchalnykh zakladakh osvity”, 2015, vyp. 27, s. 42-50.

Korol S.V., Komunikatyvnyi pidkhid u navchanni inozemnykh mov [Communicative approach in foreign language teaching], [v:] „Pedahohichnyi dyskurs”, 2012, vyp. 11, s. 133-136.

Liakh T.O., Ukrainska mova yak inozemna: profesiine movlennia. Praktychnyi kurs dlia inozemnykh studentiv medychnykh spetsialnostei VZO: Navchalnyi posibnyk [Ukrainian as foreign: professional speech. Practical course for foreign students of medical specialties in higher educational institutions: learner's guide], Uzhhorod: Hoverla, 2018.

Palamar L., Pryntsypy ukladannia pidruchnyka z ukrainskoi movy dlia inozemnykh studentiv [The principles of creating a textbook of Ukrainian language for foreign students], [v:] „Teoriia i praktyka vykladannia ukrainskoi movy yak inozemnoi”, 2008, vyp. 3, s. 40-47.

Selivestrova L., Linhvistychna ta psykholohichna osnova navchannia ukrainskoi movy yak inozemnoi [Linguistic and psychological bases of studies of Ukrainian as foreign], [v:] „Teoriia i praktyka vykladannia ukrainskoi movy yak inozemnoi”, 2007, vyp. 2, s. 8-13.

Sysoieva S.O., Interaktyvni tekhnolohii navchannia doroslykh: navchalno-metodychnyi posibnyk [Interactive technologies of adult learning: learner's guide], Kyiv: VD „EKMO”, 2011.

Sokil B., Metody vyvchennia ukrainskoi movy yak inozemnoi ta yikh kharakterystyka [Methods of study of Ukrainian as foreign and their description], [v:] ,,Teoriia i praktyka vykladannia ukrainskoi movy yak inozemnoi”, 2007, vyp. 2, s. 14-18.

Subota L., Komunikatyvna orhanizatsiia naukovoho tekstu u protsesi profesiinoi pidhotovky inozemnykh studentiv nemovnoho VNZ [Communicative organization of scientific text in the educational process of teaching international students in non-language higher educational institutions: learner's guide], [v:] „Naukovi zapysky Natsionalnoho universytetu «Ostrozka akademiia». Seriia «Filolohichna»", 2015, vyp. 53, s. 317-320.

Tyshkovets M., Vykorystannia komunikatyvnoho metodu vyvchennia ukrainskoi movy yak inozemnoi u medychnomu VNZ [Use of the communicative method of studying the Ukrainian language as a foreign language in a medical higher educational institutions], [v:] „Teoriia i praktyka vykladannia ukrainskoi movy yak inozemnoi”, 2013, vyp. 8, s. 40-48.

Ushakova N.I., Kohnityvni osnovy formuvannia komunikatyvnoi kompetentnosti inozemnykh studentiv u pidruchnyku z movy navchannia [The cognitive bases of forming the communicative competence of foreign students in the second language manual], [v:] ,Vykladannia mov u vyshchykh navchalnykh zakladakh osvity na suchasnomu etapi. Mizhpredmetni zviazky. Naukovi doslidzhennia. Dosvid. Poshuky", 2014, vyp. 25, s. 65-74.

Ushakova N., Trostynska O., Vyvchennia ukrainskoi movy studentamy-inozemtsiamy: kontseptualni zasady [Learning Ukrainian as a foreign language by international students studying in Ukrainian high schools: a conceptual basis], [v:] „Teoriia i praktyka vykladannia ukrainskoi movy yak inozemnoi”, 2014, vyp. 9, s. 12-21. 
Shumylo I.I., Formuvannia komunikatyvnoi kompetentnosti studentiv zasobamy interaktyvnykh tekhnolohii na zaniattiakh inozemnoi movy [Forming foreign language communicative competence by applying interactive technologies], [v:] „Molodyi vchenyi: Pedahohichni nauky", 2006, nr 12.1 (40), s. 559-562. 